\title{
mRNAs coding for A1 and A2 isoforms of translation factor eEF1 demonstrate different half-lives while A1 and A2 proteins are similarly stable in MCF7 cells
}

\author{
A. A. Vislovukh, N. L. Gralievska, M. G. Naumovets, B. S. Negrutskii, A. V. El'skaya \\ State Key Laboratory of Molecular and Cellular Biology \\ Institute of Molecular Biology and Genetics, NAS of Ukraine \\ 150, Akademika Zabolotnoho Str., Kyiv, Ukraine, 03680 \\ a.a.vislovukh@imbg.org.ua
}

\begin{abstract}
Eukaryotic translation elongation factor $1 A$ (eEF1A) exists as two $98 \%$ homologous isoforms eEF1A1 and eEF1A2 that are tissue/development specific and differentially linked to apoptosis/cancerogenesis. A2 is overexpressed in a number of tumors while unusual expression of A1 is observed in injured muscles. To approach a possible mechanism underlying induced changes in the relative amounts of the isoforms we examined the intrinsic stability of the proteins and their mRNAs in human cancer cells. Aim. To estimate half-life of the isoforms of eEF1A at mRNA and protein level in human cancer cells. Methods. To measure mRNA stability the transcriptional block technique was applied, with subsequent analysis of the mRNA level by qPCR. To determine the protein decay rate the translation was blocked by cycloheximide and changes in the protein level were detected by Western blot. Results. Calculation of the protein stability revealed half-life of 72 for eEF1A1 and 95 hours for eEF1A2. Half-life of EEF1A1 and EEF1A2 mRNAs were 3 and 60 hours respectively. Conclusions. Despite similar protein stability, the isoforms of eEF1A dramatically differ in the half-lives of their mRNAs, suggesting that the mRNA decay mechanism is one of the main regulators of eEF1A1/A2 amount in MCF7 cancer cells.
\end{abstract}

Keywords: eEF1A1, eEF1A2, eukaryotic translation elongation factor 1A, $m R N A$ half-life, protein half-life.

Introduction. eEF1A is one of the main components of translational apparatus that provides delivery of aminoacylated tRNA to the A site of ribosome during elongation step of protein biosynthesis [1]. eEF1A exists as two isoforms, eEF1A1 and eEF1A2. The reason behind the appearance of two rather than one isoform of eEF1A in higher vertebrates is unknown. During embryonic development eEF1A1 is expressed exclusively and ubiquitously. However, throughout postnatal development in cardiac, muscle and neuronal tissues a switch occurs from the eEF1A1 to eEF1A2 expression. This change is crucial, as the mice with a partial deletion of the EEF1A2 gene die on the $28^{\text {th }}$ day after birth [2]. eEF1A1 and eEF1A2 isoforms are $98 \%$ homologous, so is not surprising that their translation activity is similar [3]. However, these proteins are very different in non-canonical

(c) Institute of Molecular Biology and Genetics, NAS of Ukraine, 2013 functions, for instance, eEF1A1 stimulates apoptosis [4, 5] while eEF1A2 demonstrates anti-apoptotic properties [6]. Moreover, EEF1A2 is a putative proto-oncogene [7] over expressed in a variety of tumor tissues [8, 9]. As mentioned before, the expression of $A 1$ and $A 2$ in tissues is mutually exclusive. However there are examples of their induced co-expression under extreme situation like the muscle injury [10] or tumorigenesis [9, 11] suggesting special need in appearance of $A 1$ or $A 2$ isoform, respectively, during the background presence of a counterpart protein. Specific non-canonical roles of the isoforms and mechanisms controlling their respective quantities in corresponding tissues are unknown. First step towards elucidating these mechanisms is to examine intrinsic stability of the corresponding mRNAs and proteins. Breast cancer MCF7 cell line is selected for this purpose as these cells demonstrate relatively high expression level of eEF1A2. 
Materials and methods. Cell line, cycloheximide and actinomycin treatment. MCF7 cells were cultured in DMEM («Sigma», USA) growth medium with stabilized L-glutamine, contained $10 \%$ FBS («Sigma») and $1 \%$ Penicillin/Streptomycin («Sigma»). Cells were maintained at $37^{\circ} \mathrm{C}$ in a humidified atmosphere containing $5 \% \mathrm{CO}_{2}$. To determine mRNAs half-lives, MCF7 cells were treated with $5 \mu \mathrm{g} / \mathrm{ml}$ actinomycin D («Sigma»). Cells were harvested at the time points indicated in the Figures. Amount of EEF1A1/A2 mRNAs were quantified by qPCR. For protein half-life determination, MCF7 cells were incubated with $100 \mu \mathrm{g} / \mathrm{ml}$ cycloheximide («Sigma»). Cells were harvested at the time points indicated in the Figures with consequent Western blot analyses. The Western blot results were quantified by the ChemiDoc system («Bio-Rad», USA) Changes in amount of eEF1A1, eEF1A2 and GAPDH proteins were analysed by Gel Doc software («Bio-Rad»).

$q P C R$. Total RNA was isolated using TRI Reagent («Sigma»). $1 \mu \mathrm{g}$ of RNA was used for cDNA synthesis with a RevertAid Premium Reverse Transcriptase («Thermo Scientific», USA) according to manufacturer recommendations. Each reaction was performed in a mix of $20 \mu 1$ reaction mixture containing $1 \mu 1 \mathrm{cDNA}$, Maxima SYBR Green qPCR Master Mix (2×) («Thermo Scientific») and forward/reverse primers $0.3 \mu \mathrm{M}$ each. The primers for eEF1A2 qPCR and cycling conditions were described earlier [10]. Primers for beta-actin were: forward primer - 5'-GCGGGAAATCGTGCGTGAC ATT-3'; reverse primer - 5'- GATGGAGTTGAAGGT AGTTTCGTG-3'. QPCR was quantified with MyiQ real-time PCR system («Bio-Rad»). Data were analyzed using qPCR Miner 4.0 software [12].

Western blot. Total cell lysates were prepared in MPER buffer («Pierce», USA) supplemented with the protease inhibitor cocktail («Roche», France). Cells were incubated at $4{ }^{\circ} \mathrm{C}$ for $20 \mathrm{~min}$. Lysates were centrifuged and supernatant was stored in liquid nitrogen. Proteins were separated by PAGE $10 \%(29: 1)$ («Bio-Rad») and transferred to PVDF membranes («Millipore», USA). Membranes were developed using Immobi lon Western Chemiluminicsent Substrate («Millipore»).

Results and Discussion. As eEF1A2 is a putative proto-oncogene and such proteins usually are quickly degraded [13] we expected the life time of eEF1A2 to be significantly less than eEF1A1. There were several
Comparison of eEF1A2, eEF1A2 and GAPDH proteins half-lives obtained by different studies

\begin{tabular}{|c|c|c|c|c|}
\hline \multirow{2}{*}{$\begin{array}{c}\text { Protein } \\
\text { name }\end{array}$} & \multicolumn{4}{|c|}{ Half-lives of proteins, $\mathrm{h}$} \\
\hline & $\mathrm{HeLa}[14]$ & HeLa [16] & NIH 3 T3 [15] & $\mathrm{C} 2 \mathrm{C} 12[14]$ \\
\hline eEF1A1 & 75 & 56,9 & 126 & 82,3 \\
\hline eEF1A2 & $\begin{array}{c}\text { Too high for } \\
\text { detection }\end{array}$ & 83,5 & 103,16 & NA \\
\hline GAPDH & $\begin{array}{c}\text { Too high for } \\
\text { detection }\end{array}$ & 68,4 & 353,55 & 94,9 \\
\hline
\end{tabular}

datasheets on the eEF1A1 and eEF1A2 half-lives obtained from global proteomic studies examining a vast majority of cellular proteins at once [14-16]. Unfortunately, these data did not give a definite answer, even in the case the same cell line was used in different studies (Table). To clarify the issue we measured half-lives of eEF1A1 and eEF1A2 directly, using cycloheximide-treated MCF-7 cells and two kinds of antibodies, the first recognizing both $\mathrm{A} 1$ and $\mathrm{A} 2$ isoforms and the second being exclusively specific for A2 [17]. As the amount of A1 in MCF7 cells is much larger (by orders) than $\mathrm{A} 2$ we consider the former antibodies response reflects mostly the A1 amount. Cycloheximide is an antibiotic which specifically blocks elongation step of protein biosynthesis [18]. That is why it is often used for protein stability measurements [19].

Surprisingly, the eEF1A1 and eEF1A2 isoforms demonstrated similar decay rates (Fig. 1, A). Subsequent calculations revealed that the both isoforms belong to the class of long lived proteins with estimated halflives of 72 for eEF1A1 and 95 hours for eEF1A2 (Fig. $1, B)$. GAPDH which is a known long-lived protein was planned to be used as a loading control. However, as the half-life of GADPH $(61 \mathrm{~h})$ was found to be comparable with that for eEF1A1 and eEF1A2 (Fig. 1, A) we had to use strictly similar amount of cells for preparing the extract to load per line. Thus, both eEF1A1 and eEF1A2 isoforms possess comparable half-lives in the breast cancer MCF-7 cells. We suggest that protein stabilization does not seem to contribute to cancer-related change in the intracellular eEF1A1/eEF1A2 ratio and the alterations in relative amount of eEF1A1 and eEF1A2 in cancer cells are governed by the level and translation efficacy of their mRNAs. 

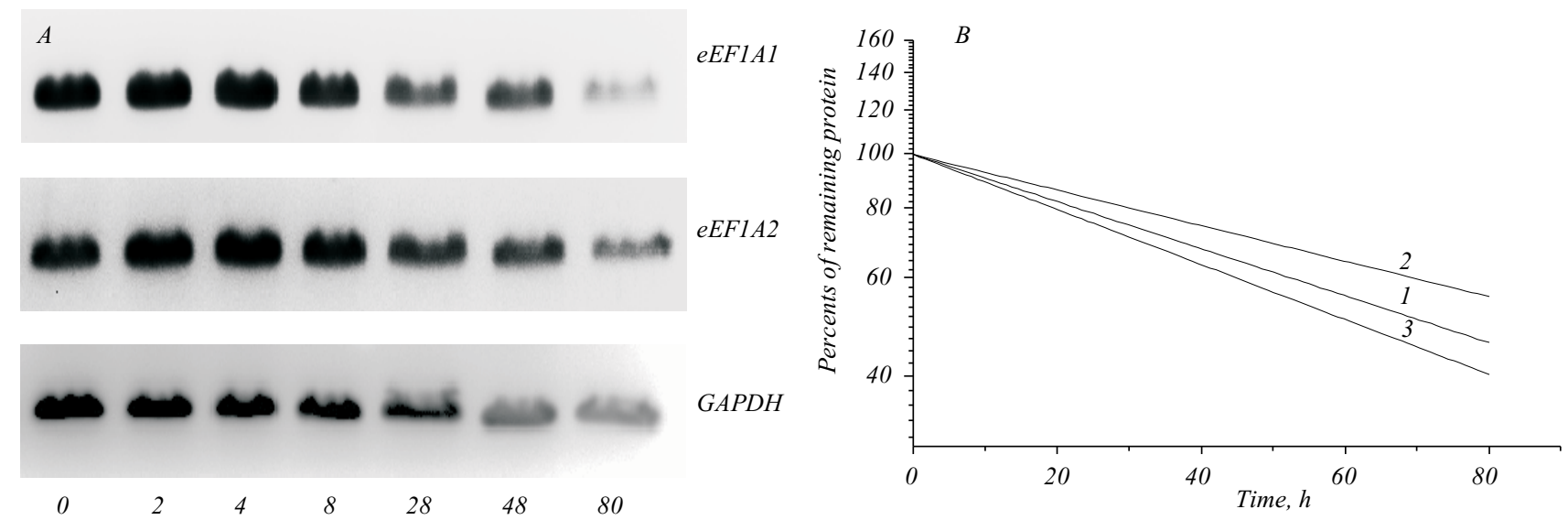

Fig. 1. Estimation of eEF1A1 and eEF1A2 half-lives in MCF7 cells: $A$ - total protein biosynthesis was blocked by cycloheximide (at the indicated time points, $3 \cdot 10^{6}$ cells were collected and analysed by Western blot with antibodies against A1/A2 and A2 proteins); $B$ - representation of the data in semi-log plot: $1-\mathrm{eEF} 1 \mathrm{~A} 1 ; 2-\mathrm{eEF} 1 \mathrm{~A} 2 ; 3-\mathrm{GAPDH}$ (data were fitted by exponential decay first order kinetic function; $t_{1 / 2}=\ln 2 / k$, where $k$ is the rate constant for protein decay)

We examined the parameter of mRNA stability by comparing the decay rates of the EEF1A1 and EEF1A2 mRNAs. mRNAs coding for the isoforms are highly homologous in open reading frames (ORF), however, they are rather different in the $3^{\prime}$ and $5^{\prime}$ untranslated regions (UTRs), which may provide a background for specific posttranscriptional control. The presence of such structural elements as CPE (cytoplasmic polyadenylation element), ARE (AU-rich element) etc. in the EEF1A1 rather than in the EEF1A2 mRNA suggests lower stability of the former. Varieties of methods were developed to quantify the decay rates of mRNA in different cell lines. The most exploited is «transcriptional shut off» method to block transcription by RNA polymerase inhibitors, with subsequent measurement of the residual amounts of mRNAs of the interest by Northern Blot or qPCR.

Therefore, MCF7 cells were treated with actinomycin D to block RNA polymerase II activity. Cells were collected after 2, 4, 8, 28, 48 and $80 \mathrm{~h}$ of incubation with consequent analysis of the EEF1A1/1A2 mRNA level by qPCR. Indeed, mRNA of eEF1A2 was found to be considerably more stable than eEF1A1 (Fig. 2). Approximate half-life times were $60 \mathrm{~h}$ for eEF1A2 and $3 \mathrm{~h}$ for eEF1A1 mRNAs. In the literature, there is the only indication of half-life measurement for the eEF1A1 mRNA [15] where Schwanhausser et al. observed that half-life of the eEF1A1 mRNA is 17,5 h. However, the authors measured mRNA decay rates in non-cancerous mouse fibroblasts (NIH3T3), while our experiments we- re carried out in MCF7 human cancer cells. Consequently such divergence in the results can be partly explained by the difference in $3^{\prime}$ UTRs of human and mouse EEF1A1 mRNAs [20]. 3' UTR of the human EEF1A1 mRNA is much longer and contains several additional instability elements. Besides, rate of the EEF1A1 mRNA decay in cancer and non-cancerous cells may be different.

It is known that transcription of the EEF1A1 mRNA occurs very powerfully, the promoter region of eefla gene is the second most efficient after cytomegalovirus one [21]. Moreover the EEF1A1 mRNA belongs to the TOP class of mRNAs [22] and consequently A1 can be rapidly synthesized in response to the growth stimuli. It should be mentioned that the EEF1A2 mRNA also contains a non-canonical TOP element [23], however its functionality is still questionable. We discover now that to prevent over saturation of a cell with rather stable protein eEF1A1 a novel mechanism was elaborated which includes rapid degradation of EEF1A1 mRNA soon after its synthesis. Thus, repression of transcription of the eEF1A1 mRNA appears to be though not very fast but reliable way to decrease the amount of eEF1A1 protein with subsequent inhibition of translation elongation. The proto-oncogenic eEF1A2 protein may be much less controlled by means of down-regulation of transcription or translation. Interestingly, eEF1A2 is exclusively expressed in such very important cells as myocytes and neurons $[3,24]$. Virtual absence of the possibility to quickly alter its amount may provide additional reliability and stability of the protein synthesis in these terminally dif- 


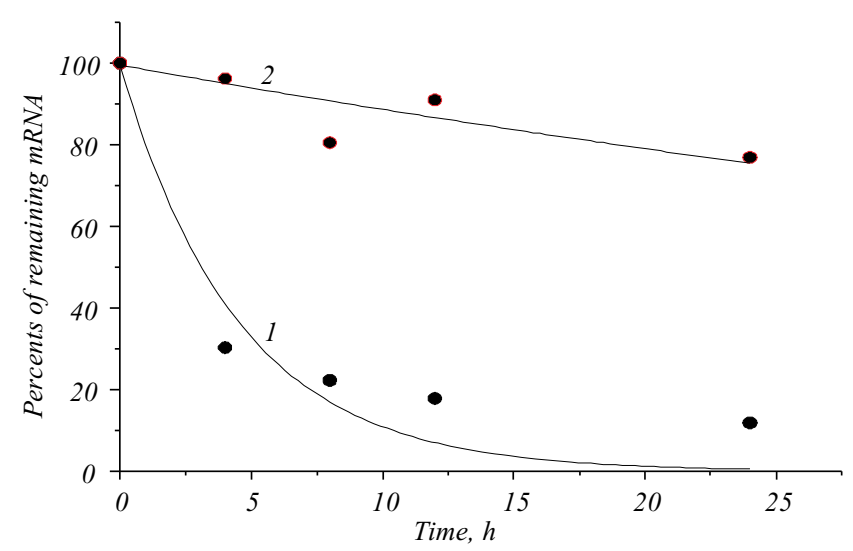

Fig. 2. Estimation of EEF1A1 (1) and EEF1A2 (2) mRNAs stability in MCF7 cells. Transcription was blocked by actinomycin D. At the time points indicated, the samples were collected and qPCR analyses of EEF1A1/A2 mRNAs was carried out. Data were fitted by exponential decay first order kinetic function; $t_{1 / 2}=\ln 2 / k$, where $k$ is the rate constant for mRNA decay

ferentiated cells. On the other hand, over expression of eEF1A2 could be very harmful for cells and lead to oncogenesis [8]. To control the amount of eEF1A2, a cell has elaborated another mechanism, exactly down-regulation of eEF1A2 by microRNA-663 and 744 recently described by us [25]. The organism seems to keep the eEF1A2 expression under a tight control, limiting its appearance in terminally differentiated cells. On the contrary, eEF1A1 is normally found everywhere in the organism except muscles and neurons. The eEF1A1 mRNA, opposite to A2, has short, TOP class 5' UTR and long 3' UTR which opens wide «place d'arme» to the transfactors [20,26]. Consequently, this mRNA has much shorter half-life, that also contributes to the regulatory process.

For instance, the neurons respond to electric stimuli via certain parts of the dendrites rather than via whole soma [27]. In that case, local protein biosynthesis and/or cytoskeleton reorganization should be activated to afford neuronal plasticity [28]. We assume that the eEF1A2 mRNA being stable may provide homeostasis and stability of the soma, while the EEF1A1 mRNA could be responsible for the fast structural changes via cytoskeleton reorganization and local protein biosynthesis in distal compartments of neuron. It is already known that upon LTP (long term potentiation) formation in such distal compartments as dendrites, mTOR-induced translation of the eEF1A1 mRNA is observed [29-31]. Another example is muscles, where the isoform eEF1A2 is the only one, while the induction of EEF1A1 expression is observed during regeneration processes after muscle injury [10]. After healing is finished the eEF1A1 mRNA can degrade quickly because of low half-life, permitting to restore the normal functioning. Interestingly, muscles healing process largely recapitulates embryonic myogenesis where the only eEF1A1 isoform is present [32].

Besides, high level of homology and similar catalytic function during protein biosynthesis, the isoforms of eEF1A are very different in their numerous non-canonical functions.

Combining our and literature data we put forward a novel concept stating that the existence of the two highly homologous isoforms of human eEF1A can be explained by the necessity of cells to control selectively expression of the eEF1A1/A2 isoforms at different levels and by different mechanisms depending on their canonical and non-canonical functions.

eEF1A1 is constitutively expressed in majority of the organs in the organism providing a basic level of protein synthesis responsive to different kinds of regulation. Appearance of eEF1A2 in the same tissues seems not to respond to the same regulatory factors, therefore, may be very harmful for cells.

Conclusions. The data show that the isoforms of eEF1A demonstrate very different half-lives of mRNA but similar stability of corresponding proteins. We assume that the mRNA decay mechanism is one of the main regulators of eEF1A1 expression, at least, in the human breast cancer MCF7 cells.

\section{А. А. Вісловух, Н. Л. Гралєвська, М. Г. Наумовецьь, \\ Б. С. Негруцький, А. В. Сльська}

мРНК, що кодують А1 і А2 ізоформи фактора трансляції еEF1, мають різний час напівжиття, у той час як білки А1 і А2 рівною мірою стабільні в клітинах MCF7

\section{Резюме}

Евкаріотний фактор елонгачії трансляиії (еЕF1А) існує у вигляді двох гомологічних на $98 \%$ ізоформ еЕF1A1 і еЕF1A2, які є тканиноспецифічними, відрізняються за представленістю в онтогенезі та по-різному пов'язані з апоптозом і канцерогенезом. Згідно з попередніми даними, еЕF1A2 має підвищений рівень експресії у деяких пухлинах, а еЕF1A1 - у пошкоджених м'язах. Щоб зрозуміти механізм, за яким змінюється відносна кількість ізоформ, ми дослідили стабільність білків та їхніх мРНК у клітинах раку людини. Мета. Оцінити час напівжиття ізоформ еЕF1А на рівні мРНК $і$ білка в клітинах раку людини. Методи. Для вимірювання стабільності мРНК використано техніку блокування транскрип- 
иії з подальшим аналізом рівня мРНК із застосуванням кількісної ПЛР. Для визначення швидкості розпаду білка трансляцію блокували ииклогексимідом, подальші зміни рівня білка виявляли методом Вестерн-блоту. Результати. За підрахунками, стабільність білка зберігалася протягом 72 год у разі еEF1A1 та 95 год - у разі еEF1A2. Значення часу напівжиття EEF1A1 $і$ EEF1A2 мPHK становлять відповідно 3 і 60 год. Висновки. Незважаючи на подібні значення стабільності білка, ізоформи еЕF1A значно відрізняються за часом напівжсиття їхніх мРНК, внаслідок чого можна припустити, щзо контроль стабільності мРНК $є$ одним з основних механізмів регуляиії експресії еEF1A1/ A2 в клітинах раку молочної залози МCF7.

Ключові слова: еEF1A1, еЕF1A2, евкаріотний фактор елонгаиіï транслячіï $1 A$, час напівжиття мРНК, час напівжиття білка.

А. А. Висловух, Н. Л. Гралевская, М. Г. Наумовеи, Б. С. Негруикий, А. В. Ельская

мРНК, кодирующие А1 и А2 изоформы фактора трансляции eEF1, имеют различное время полужизни, а белки A1 и A2 в равной степени стабильны в клетках MCF7

\section{Резюме}

Эукариотический фактор элонгаџии трансляции (еЕF1A) существует в виде двух гомологичных на $98 \%$ изоформ еЕF1A1 и еEF1A2, являюшихся тканеспецифическими, отличаюшихся представленностью в онтогенезе и по-разному связанных с апоптозом и каниерогенезом. Согласно наблюдениям, еEF1A2 имеет повышенный уровень экспрессии в некоторых опухолях, а еЕF1A1 в поврежденных мышиах. Чтобы понять механизм, по которому изменяется относительное количество изоформ, мы исследовали стабильность белков и их мРНК в клетках рака человека. Цель. Оиенить время полужизни изоформ еЕF1А на уровне мРНК и белка в клетках рака человека. Методы. Для измерения стабильности мРНК использовали технику блокирования транскрипции с последуюшим анализом уровня мРНК с применением количественной ПЦР. Для определения скорости распада белка трансляиию блокировали циклогексимидом, дальнейшие изменения уровня белка выявляли методом Вестерн-блота. Результаты. По расчетам, стабильность белка сохранялась в течение 72 ч в случае еEF1A1 и 95 ч - в случае еEF1A2. Время полужизни EEF1A1 и EЕF1A2 мРНК составляло соответственно 3 и 60 ч. Выводы. Несмотря на подобные значения стабильности белка, изоформы еEF1A значительно отличаются по времени полужизни их мРНК, вследствие чего можно предположить, что контроль стабильности мРНК является одним из основных механизмов регуляции экспрессии еЕF1A1/A2 в клетках рака молочной железы MCF7.

Ключевые слова: еЕF1A1, еЕF1A2, эукариотический фактор элонгации трансляции 1 , время полужсизни мРНК, время полужизни белка.

\section{REFERENCES}

1. Negrutskii B. S., El'skaya A. V. Eukaryotic translation elongation factor 1 alpha: structure, expression, functions, and possible role in aminoacyl-tRNA channeling // Prog. Nucleic Acid Res. Mol. Biol.-1998.-60.-P. 47-78.

2. Newbery H. J., Loh D. H., O'Donoghue J. E., Tomlinson V. A., Chau Y. Y., Boyd J. A., Bergmann J. H., Brownstein D., Abbott C. M. Translation elongation factor eEF1A2 is essential for post-weaning survival in mice // J. Biol. Chem.-2007.-282, N 39.P. 28951-28959.
3. Kahns S., Lund A., Kristensen P., Knudsen C. R., Clark B. F., Cavallius J., Merrick W. C. The elongation factor 1 A-2 isoform from rabbit: cloning of the cDNA and characterization of the protein // Nucleic Acids Res.-1998.-26, N 8.-P. 1884-1890.

4. Chen E., Proestou G., Bourbeau D., Wang E. Rapid up-regulation of peptide elongation factor EF-1alpha protein levels is an immediate early event during oxidative stress-induced apoptosis // Exp. Cell Res.-2000.-259, N 1.-P. 140-148.

5. Duttaroy A., Bourbeau D., Wang X. L., Wang E. Apoptosis rate can be accelerated or decelerated by overexpression or reduction of the level of elongation factor-1 alpha // Exp. Cell Res.1998.-238, N 1.-P. 168-176.

6. Ruest L. B., Marcotte R., Wang E. Peptide elongation factor eEF1A-2/S1 expression in cultured differentiated myotubes and its protective effect against caspase-3-mediated apoptosis // J. Biol. Chem.-2002.-277, N 7.-P. 5418-5425.

7. Anand N., Murthy S., Amann G., Wernick M., Porter L. A., Cukier I. H., Collins C., Gray J. W., Diebold J., Demetrick D. J., Lee J. $M$. Protein elongation factor EEF1A2 is a putative oncogene in ovarian cancer // Nat. Genet.-2002.-31, N 3.-P. 301-305.

8. Lee M. H., Surh Y. J. eEF1A2 as a putative oncogene // Ann. New York Acad. Sci.-2009.-1171.-P. 87-93.

9. Tomlinson V. A., Newbery H. J., Wray N. R., Jackson J., Larionov A., Miller W. R., Dixon J. M., Abbott C. M. Translation elongation factor eEF1A2 is a potential oncoprotein that is overexpressed in two-thirds of breast tumours // BMC Cancer.2005.-5.-P. 113.

10. Bosutti A., Scaggiante B., Grassi G., Guarnieri G., Biolo G. Overexpression of the elongation factor $1 \mathrm{~A} 1$ relates to muscle proteolysis and proapoptotic p66(ShcA) gene transcription in hypercatabolic trauma patients // Metabolism.-2007.-56, N 12.P. 1629-1634.

11. Tomlinson V. A., Newbery H. J., Bergmann J. H., Boyd J., Scott D., Wray N. R., Sellar G. C., Gabra H., Graham A., Williams A. R., Abbott C. M. Expression of eEF1A2 is associated with clear cell histology in ovarian carcinomas: overexpression of the gene is not dependent on modifications at the EEF1A2 locus // Br. J. Cancer.-2007.-96, N 10.-P. 1613-1620.

12. Zhao S., Fernald R. D. Comprehensive algorithm for quantitative real-time polymerase chain reaction // J. Comput. Biol.2005.-12, N 8.-P. 1047-1064.

13. Goldberg A. L. Protein degradation and protection against misfolded or damaged proteins // Nature.-2003.-426, N 6968.P. 895-899.

14. Cambridge S. B., Gnad F., Nguyen C., Bermejo J. L., Kruger M., Mann M. Systems-wide proteomic analysis in mammalian cells reveals conserved, functional protein turnover // J. Proteome Res.-2011.-10, N 12.-P. 5275-5284.

15. Schwanhausser B., Busse D., Li N., Dittmar G., Schuchhardt J., Wolf J., Chen W., Selbach M. Global quantification of mammalian gene expression control // Nature.-2011.-473, N 7347.P. 337-342.

16. Boisvert F. M., Ahmad Y., Gierlinski M., Charriere F., Lamont D., Scott M., Barton G., Lamond A. I. A quantitative spatial proteomics analysis of proteome turnover in human cells // Mol. Cell Proteomics.-2012.-11, N 3.-M111.011429.

17. Kolesanova E. F., Farafonova T. E., Aleshina E. Y., Pyndyk N. V., Veremieva M. V., Novosylnaya A. V., Kovalenko M. I., Shalak V. F., Negrutskii B. S. Preparation of monospecific antibodies against isoform 2 of translation elongation factor $1 \mathrm{~A}$ (eEF1 A2) // Biochemistry (Moscow) Supplement Series B: Biomedical Chemistry.-2013.-7, N 1.-P. 62-69.

18. Obrig T. G., Culp W. J., McKeehan W. L., Hardesty B. The mechanism by which cycloheximide and related glutarimide an- 
tibiotics inhibit peptide synthesis on reticulocyte ribosomes // J. Biol. Chem.-1971.-246, N 1.-P. 174-181.

19. Zhou P. Determining protein half-lives // Methods Mol. Biol.2004.-284.-P. 67-77.

20. Vislovukh A. A., Naumovets M. G., Kovalenko M. I., Groisman R. S., Groisman I. S., Negrutskii B. S., El'skaya A. V. Isoforms of elongation factor eEF1A may be differently regulated at posttranscriptional level in breast cancer progression // Biopolym. Cell.-2013,-29, N 1,-P. 55-63.

21. Kim D. W., Uetsuki T., Kaziro Y., Yamaguchi N., Sugano S. Use of the human elongation factor 1 alpha promoter as a versatile and efficient expression system // Gene.-1990.-91, N 2.-P. 217-223.

22. Shibui-Nihei A., Ohmori Y., Yoshida K., Imai J., Oosuga I., Iidaka M., Suzuki Y., Mizushima-Sugano J., Yoshitomo-Nakagawa K., Sugano $S$. The 5' terminal oligopyrimidine tract of human elongation factor 1A-1 gene functions as a transcriptional initiator and produces a variable number of Us at the transcriptional level // Gene.-2003.-311.-P. 137-145.

23. Datu A. K., Bag J. Enhanced translation of mRNAs encoding proteins involved in mRNA translation during recovery from heat shock // PLoS One.-2013.-8, N 5.-e64171.

24. Knudsen S. M., Frydenberg J., Clark B. F., Leffers H. Tissuedependent variation in the expression of elongation factor-1 alpha isoforms: isolation and characterisation of a cDNA encoding a novel variant of human elongation-factor 1 alpha // Eur. J. Biochem.-1993.-215, N 3.-P. 549-554.

25. Vislovukh A., Kratassiouk G., Porto E., Gralievska N., Beldiman C., Pinna G., El'skaya A., Harel-Bellan A., Negrutskii B., Groisman I. Proto-oncogenic isoform A2 of eukaryotic translation elongation factor eEF1 is a target of miR-663 and miR-744 // Br. J. Cancer.-2013.-108, N 11.-P. 2304-2311.

26. Vislovukh A. A., Groisman I. S., El'skaya A. V., Negrutskii B. S., Polesskaya A. N. Transcriptional and post-transcriptional control of eEF1A2 expression during myoblast diffrerentiation // Biopolym. Cell.-2012.-28, N 6.-P. 456-460.

27. Schuman E. M., Dynes J. L., Steward O. Synaptic regulation of translation of dendritic mRNAs //J. Neurosci.-2006.-26, N 27.P. 7143-7146.

28. Jung H., Yoon B. C., Holt C. E. Axonal mRNA localization and local protein synthesis in nervous system assembly, maintenance and repair // Nat. Rev. Neurosci.-2012.-13, N 5.-P. 308-324.

29. Grange J., Belly A., Dupas S., Trembleau A., Sadoul R., Goldberg $Y$. Specific interaction between Sam68 and neuronal mRNAs: implication for the activity-dependent biosynthesis of elongation factor eEF1A // J. Neurosci. Res.-2009.-87, N 1.-P. 12-25.

30. Hashimoto K., Ishima T. Neurite outgrowth mediated by translation elongation factor eEF1A1: a target for antiplatelet agent cilostazol // PLoS One.-2011.-6, N 3.-e17431.

31. Tsokas P., Grace E. A., Chan P., Ma T., Sealfon S. C., Iyengar R., Landau E. M., Blitzer R. D. Local protein synthesis mediates a rapid increase in dendritic elongation factor $1 \mathrm{~A}$ after induction of late long-term potentiation // J. Neurosci.-2005.-25, N 24.P. 5833-5843.

32. Swynghedauw B. Developmental and functional adaptation of contractile proteins in cardiac and skeletal muscles // Physiol. Rev.-1986.-66, N 3.-P. 710-771. 